\title{
Gynecomastia: A Rare Adverse Effect of Methylphenidate in an Adolescent Boy
}

\author{
Ali Karayagmurlu, Ayse Tugce Varli, Murat Coskun \\ Department of Child and Adolescent Psychiatry, Istanbul Medical Faculty, Istanbul University, Istanbul, Turkey
}

\begin{abstract}
Gynecomastia is a benign condition developing in association with localized fat deposition and glandular tissue proliferation in the breast in males, and characterized by breast growth. Drug is one of the most important factors in the etiology of gynecomastia. Methylphenidate is a commonly preferred and well-tolerated drug in the treatment of attention deficit hyperactivity disorder in children and adolescents. Gynecomastia is an uncommon side-effect of methylphenidate use. We report a case of bilateral gynecomastia developing in a dose-dependent manner during methylphenidate monotherapy and resolving with discontinuation of medication in a 15-year-old patient with a history of a similar side-effect during previous use of the drug. To the best of our knowledge this is one of the few case reports of gynecomastia developing in association with methylphenidate.
\end{abstract}

KEY WORDS: Gynecomastia; Methylphenidate; Adverse effect; Adolescent.

\section{INTRODUCTION}

Gynecomastia is a benign condition characterized by breast growth in males. It develops in association with localized fat deposition and glandular tissue proliferation in the breast. Proliferation of male breast tissue may be seen at any age, and may be uni- or bilateral [1]. Neyzi et al. [2] reported a prevalence of gynecomastia of $7 \%$. Several factors may be involved in the etiology of gynecomastia. Among these factors, the drug-related gynecomastia was one of the leading causes [3]. Various medications are capable of causing gynecomastia, including diazepam, haloperidol, phenothiazine and tricyclic antidepressants [4]. Methylphenidate $(\mathrm{MPH})$, the first-line treatment for attention deficit hyperactivity disorder (ADHD), is effective and well-tolerated. Gynecomastia is a rare side-effect during MPH therapy. To the best of our knowledge, there have been few case reports of the condition developing as a side-effect of MPH $[5,6]$. We report a case of an adoles-

Received: August 10, 2018/ Accepted: October 9, 2018

Address for correspondence: Ali Karayagmurlu

Department of Child and Adolescent Psychiatry, Istanbul University Medical Faculty, İstanbul Tip Fakültesi Esnaf Hastanesi Klinikleri, Süleymaniye Mah. 34116 Istanbul, Turkey

E-mail: dralikarayagmurlu@gmail.com

ORCID: https://orcid.org/0000-0001-5464-2891 cent boy developing bilateral, dose-dependent gynecomastia during MPH monotherapy.

\section{CASE}

A 15-year-old boy presented with his mother due to the complaints of symptoms of ADHD including hyperactivity, impulsivity and inattentiveness. Anamnesis taken from the mother revealed that the patient had used the osmotic-release oral system (OROS) MPH (Concerta; Jansen-Cliang Manufacturing LLC., Gurabo, Porto Riko) formulation for ADHD, which he had benefitted from $\mathrm{MPH}$ at that time, but that they had discontinued the treatment of their own volition for the previous two years. Since the patient had previously benefited from $\mathrm{MPH}$ for ADHD, he was started on OROS MPH (Concerta) at 27 $\mathrm{mg} /$ day and invited to follow-up one month later. At follow-up we learned that he had failed to benefit from 27 mg/day OROS MPH (Concerta), and the dosage was raised to $36 \mathrm{mg}$ OROS MPH (Concerta). At follow-up one month subsequently, the patient reported swelling and growth in the breast following dosage enhancement, and stated that this had a psychologically adverse impact on him. The pediatric endocrinology department was then consulted. At consultation, the patient's prolactin was 7.86

(c) This is an Open-Access article distributed under the terms of the Creative Commons Attribution Non-Commercial License (http://creativecommons.org/licenses/by-nc/4.0) which permits unrestricted non-commercial use, distribution, and reproduction in any medium, provided the original work is properly cited. 
$\mathrm{ng} / \mathrm{ml}$ (normal range, $<15 \mathrm{ng} / \mathrm{ml}$ ), and no tenderness or galactorrhea were present. The patient weighed $52 \mathrm{~kg}$ (10th - 25th percentiles) and was $175 \mathrm{~cm}$ in height (10th -25 th percentiles). His body mass index was 16.97 $\mathrm{kg} / \mathrm{m}^{2}$. He denied the use of any drug, herbal product or substance. Bilateral gynecomastia was diagnosed by the endocrinology department, and the drug discontinuation was recommended. OROS MPH (Concerta) therapy was stopped, and the patient was started in atomoxetine (ATX) $50 \mathrm{mg} /$ day. When we re-evaluated his previous history, the same side-effect had previously been observed with $27 \mathrm{mg}$ OROS MPH (Concerta), but that the patient had been reluctant to disclose this at the initial interview due to embarrassment. At one-month follow-up we learned from the family that the breast growth had been reversed, but that the patient's attention problems persisted, that he was short-tempered and irritable, and that he had been involved in arguments with teachers at school. Risperidone $1 \mathrm{mg} /$ day was then added to treatment, and ATX was increased to $60 \mathrm{mg} /$ day. At the subsequent follow-up his irritability had decreased. The patient was monitored with ATX $60 \mathrm{mg} /$ day and risperdal $1 \mathrm{mg} /$ day for a period of one year. He benefited from treatment during that period, and no recurrence of gynecomastia was observed.

\section{DISCUSSION}

$\mathrm{MPH}$ is a commonly preferred and well-tolerated drug in the treatment of children and adolescents. However, some side-effects may occur during treatment. Commonly reported side-effects during MPH therapy include nausea, lack of appetite, weight loss, and sleep disturbances [7]. In addition to these widespread side-effects, MPH has also been reported to cause rare side-effects such as skin eruptions [8,9], inappropriate sexual behavior [10], obsessive compulsive symptoms [11], hallucinations [12], painful muscle cramps [13], hyperhidrosis [14] and excessive and frequent menstrual bleeding [15].

Only a few reports of $\mathrm{MPH}$-induced gynecomastia have appeared in the literature. Cosskun et al. [6] reported gynecomastia during OROS MPH (Concerta) use in a boy of 10 [6]. Ensat et al. [5] reported unilateral gynecomastia associated with MPH use in a six-year-old boy. The case of Cosskun et al. [6] used paroxetine and MPH therapy, and gynecomastia occurred six months after dosage increase. No regression in gynecomastia occurred after the drug discontinuation. Similarly, no regression was observed after discontinuation in the case of Ensat et al. [5] In our case, however, MPH-related gynecomastia improved after drug stoppage. In a review study, Bowman et al. [3] also reported that drug-related gynecomastia frequently improves after stoppage. From that perspective, our case is in line with previous reports. In our case, gynecomastia emerged immediately after the drug dosage was increased. In the two other cases, the condition emerged independently of dosage and six months after dosage increase. In our case, only the OROS MPH (Concerta) formulation was being used when gynecomastia developed. Our case was evaluated with the Naranjo Adverse Drug Reaction Probability Scale (NADRPS). On this scale, a score $\geq 9$ is regarded as definite, a score between 5 and 8 is considered probable, a score between 1 and 4 is considered possible, and a score of 0 is regarded as doubtful [16]. Our case's NADRPS score was 9. Gynecomastia is a physically and socially disturbing psychosocial problem for adolescents with adverse impacts on quality of life and self-esteem. Although gynecomastia had developed previously in our patient in association with the same medication, he was too embarrassed to mention this at interview. Arslan et al. [17] revealed that gynecomastia impaired body perception, self-esteem, and psychosocial functionality in adolescents. Nuzzi et al. [18] also reported adverse psychosocial impacts of gynecomastia in adolescents.

The pathophysiological mechanism by which $\mathrm{MPH}$ gives rise to gynecomastia is uncertain. Various mechanisms have been proposed in the development of the condition, including increased estrogen production (increased concentrations in serum and tissue), decreased androgen production or effects thereof, and hypersensitive breast tissue $[19,20]$. Impaired hormone balance plays a key role in all these hypotheses. Low testosterone to estradiol and adrenal androgens to estradiol ratios have been determined in cases of prepubertal gynecomastia [21]. In an animal study of the androgenic effects of MPH in rats, Adriani et al. [22] reported a marked decrease in testosterone concentrations with $\mathrm{MPH}$. Testosterone levels decreased significantly, by $40 \%$, in rats treated with $\mathrm{MPH}$ compared to control animals. This study suggests that a decreased androgen effect associated with decreased testosterone levels may be responsible for $\mathrm{MPH}$-induced gynecomastia. 
Treatment in our case was switched to ATX following the development of MPH-related gynecomastia. The patient was followed-up for a one-year period after switching to ATX, and no gynecomastia was observed. To the best of our knowledge, there have been no reports of ATX-related gynecomastia. We therefore elected to use ATX, and no problems were encountered in management of treatment.

Although MPH-related gynecomastia is a rare situation, it developed following an increase in MPH dosage in our case. Clinicians should therefore consider the possibility of gynecomastia with MPH therapy. It will also be beneficial for clinicians to consider ATX as an alternative in the management of $\mathrm{MPH}$-related gynecomastia.

\section{Conflicts of Interest}

No potential conflict of interest relevant to this article was reported.

\section{Author Contributions}

Conceptualization: Ayse Tugce Varli, Ali Karayagmurlu, Murat Coskun. Data acquisition: Ali Karayagmurlu. Supervision: Ali Karayagmurlu, Murat Coskun. Writingoriginal draft: Ayse Tugce Varli, Ali Karayagmurlu. Writing —review \& editing: Ali Karayagmurlu, Murat Coskun.

\section{ORCID}

Ali Karayagmurlu https://orcid.org/0000-0001-5464-2891 Ayse Tugce Varli https://orcid.org/0000-0002-5896-2195 Murat Coskun https://orcid.org/0000-0002-4808-5870

\section{REFERENCES}

1. Barros AC, Sampaio Mde C. Gynecomastia: physiopathology, evaluation and treatment. Sao Paulo Med J 2012;130:187197.

2. Neyzi O, Alp H, Yalcindag A, Yakacikli S, Orphon A. Sexual maturation in Turkish boys. Ann Hum Biol 1975;2:251-259.

3. Bowman JD, Kim H, Bustamante JJ. Drug-induced gynecomastia. Pharmacotherapy 2012;32:1123-1140.

4. Braunstein GD. Gynecomastia. N Engl J Med 1993;328:490495.

5. Ensat F, Edelbauer M, Wechselberger G. Unilateral gynecomastia in a prepubertal boy. Eur J Pediatr 2012;171:197.

6. Coskun M, Adak I, Akaltun I. Bilateral gynecomastia in a preadolescent boy while under treatment with methylphenidate and paroxetine. J Clin Psychopharmacol 2014;34:537-538.

7. Green WH. Sympathomimetic amines and central nervous system stimulants. In: Green WH. Child and adolescent clinical psychopharmacology. 4th ed. Philadelphia:LWW;2007. p.55-90.

8. Coskun M, Tutkunkardas MD, Zoroglu S. OROS methylphenidate-induced skin eruptions. I Child Adolesc Psychopharmacol 2009; 19:593-594.

9. Kaya I, Coskun M. Diffuse maculopapular rash with increasing dosage of methylphenidate. J Clin Psychopharmacol 2016;36:106-107.

10. Coskun M, Zoroglu S. A report of two cases of sexual side effects with OROS methylphenidate. I Child Adolesc Psychopharmacol 2009; 19:477-479.

11. Coşkun M. Methylphenidate induced obsessive-compulsive symptoms treated with sertraline. Klin Psikofarmakol BulteniBull Clin Psychopharmacol 2011;21:274.

12. Coskun M, Zoroglu S. Tactile and visual hallucinations in a child with methylphenidate and fluoxetine combination. J Clin Psychopharmacol 2008;28:723-725.

13. Coskun M, Kaya I. Painful muscle cramps possibly associated with withdrawal from methylphenidate. J Child Adolesc Psychopharmacol 2016;26:658-659.

14. Adak I, Kaya I, Coskun M. Methylphenidate-induced hyperhidrosis in an adolescent boy. Anatol Clin JMed Sci 2017;22: 50-52.

15. Coskun M, Adak I. Excessive and frequent menstrual bleeding with methylphenidate in an adolescent girl with attention-deficit hyperactivity disorder. J Clin Psychopharmacol 2017;37:637-639.

16. Naranjo CA, Busto U, Sellers EM, Sandor P, Ruiz I, Roberts EA, et al. A method for estimating the probability of adverse drug reactions. Clin Pharmacol Ther 1981;30:239-245.

17. Arslan S. Jinekomastisi olan ergenlerde psikopatoloji benlik sayg1s1 ve beden alg1s1 erzurum: child and adolescent psychiatry. Erzurum:Atatürk University;2015. [Dissertation]. Turkish.

18. Nuzzi LC, Cerrato FE, Erikson CR, Webb ML, Rosen H, Walsh EM, et al. Psychosocial impact of adolescent gynecomastia: a prospective case-control study. Plast Reconstr Surg 2013; 131:890-896.

19. Ismail AA, Barth JH. Endocrinology of gynaecomastia. Ann Clin Biochem 2001;38:596-607.

20. Braunstein GD, Glassman HA. Gynecomastia. Curr Ther Endocrinol Metab 1997;6:401-404.

21. Biro FM, Lucky AW, Huster GA, Morrison JA. Hormonal studies and physical maturation in adolescent gynecomastia. J Pediatr 1990;1 16:450-455.

22. Adriani W, Leo D, Guarino M, Natoli A, Di Consiglio E, De Angelis G, et al. Short-term effects of adolescent methylphenidate exposure on brain striatal gene expression and sexual/endocrine parameters in male rats. Ann $N Y$ Acad Sci 2006;1074:52-73. 